\title{
TRACE ELEMENTS IN GARNETS FROM TANZANIAN KIMBERLITES: RELATION TO DIAMOND CONTENT AND TECTONIC SETTING.
}

\author{
W.L. Griffin ${ }^{(1)}$; C.G. Ryan ${ }^{(2)}$; S.Y. O'Reilly ${ }^{(2)}$; P.H. Nixon ${ }^{(3)}$ and T.T. Win ${ }^{(1)}$.
}

(1) CSIRO Div. of Exploration Geoscience, Box 136, N. Ryde, NSW 2113, Australia; (2) School of Earth Sciences, Macquarie University, Sydney 2009, Australia; (3) Dept. of Earth Sciences, Univ. of Leeds, Leeds LS2 9JT, U.K.

Introduction: The Tanzanian craton contains $>400$ known kimberlite occurrences, divided geographically into an Eastern and a Western zone (Nixon \& Condliffe, 1989). The Western Zone includes both diamondiferous pipes (including Mwadui) and barren ones. The kimberlites of the Eastern Zone, closer to the craton margin, apparently are all barren. Tanzania is therefore a good example of an area with abundant targets for exploration, in which rapid evaluation and ranking of targets is important in limiting the cost of exploration and testing. The major-element composition of concentrate garnets commonly plays an important role in such evaluation, but involves several levels of ambiguity. For example, subcalcic ("G10") pyropes are known from many barren deposits (Kuruman province; Sekameng), while some economic deposits (e.g Argyle) contain few if any subcalcic pyropes.

In this work we have used trace-element data, obtained by proton microprobe, to add another level of discrimination to the use of garnets in target evaluation. The Ni content of garnet is strongly temperature-dependent (Griffin et al., 1989a), and this "Nickel Thermometer" provides key data for the more sophisticated interpretation of garnet concentrate data. In an area with a "cratonic" geotherm, the diamond stability field lies between ca. $950^{\circ} \mathrm{C}$ (the intersection of the geotherm with the diamond stability field) and ca. $1250^{\circ} \mathrm{C}$ (roughly the base of the lithosphere). The proportion of concentrate garnets within this "diamond window" is a measure of whether the kimberlite has sampled potentially diamond-bearing mantle. Other elements, such as $\mathrm{Zr}, \mathrm{Y}, \mathrm{Ti}$ and $\mathrm{Ga}$, provide information on the degree of depletion, and on the nature and extent of metasomatic processes.

Data: Cr-pyrope garnets are abundant in most pipes in the area. There is a similar range of Ca and $\mathrm{Cr}$ contents, and a similar abundance of moderately subcalcic garnets, in the kimberlites of both zones. In the Western Zone, subcalcic pyropes occur in both diamond-bearing and barren pipes (Nixon \& Condliffe, 1989). Fig. 1 compares the distribution of nickel temperatures in pipes from the Eastern Zone (mainly Makibulei) with those from barren (mainly 80K6, 99K2) and diamond-bearing pipes (mainly Mwadui, Sultan) in the Western Zone. There is a clear difference between the barren and diamondiferous pipes in the Western Zone; the diamondiferous ones contain a significant proportion of garnets in the "diamond window", whereas these garnets are almost absent in the barren pipes. Both barren and diamondiferous pipes also contain a population of garnets with $\mathrm{T}>1250^{\circ} \mathrm{C}$. The garnets from the Eastern Zone kimberlites show a major peak lying on the low-T side of the diamond window, as well as the high-T population seen in the Western Zone pipes.

The high- $\mathrm{T}$ group in all three groups is similar in composition; $\mathrm{Cr} 2 \mathrm{O} 3$ is $1-3 \%, \mathrm{Zr}$ is mainly $>50 \mathrm{ppm}, \mathrm{Zr} / \mathrm{Y}$ is nearly constant at 4 (Fig. 2), and TiO2 is high (0.2-1\%) and strongly correlated with $\mathrm{Zr}$ (Fig. 3). The garnets within the diamond window are mostly enriched, with 20-50 ppm Zr, Zr/Y = 2-4, and relatively high Y/Ga (Fig. 4). These values are typical of garnets from relatively fertile lherzolites. Some garnets show high $\mathrm{Zr}$ without corresponding $\mathrm{Ti}$ enrichment, and are similar to garnets from phlogopite-bearing peridotites, which are inferred to have experienced hydrous metasomatism.

The low-T garnets of the barren Western Zone kimberlites have generally low $\mathrm{Zr}(0-40$ ppm, aver. ca. $20 \mathrm{ppm}$ ); many of these also have low Y contents, and probably are derived from depleted lherzolites. A separate population has high $\mathrm{Y}$ and $\mathrm{Y} / \mathrm{Ga}$, with $\mathrm{Zr} / \mathrm{Y}<1$. These are typical of many low-T,P garnets, and reflect the partitioning of $\mathrm{Y}$ into garnet, and $\mathrm{Zr}$ into cpx, with decreasing T (O'Reilly \& Griffin, 1989). The low-T garnets of the Eastern Zone show a wide range of $\mathrm{Zr}$ contents. Most higher- $\mathrm{Zr}$ ones $(\mathrm{Zr}>50 \mathrm{ppm})$ also show Ti enrichment. The rest are either very depleted (low-Zr,Y) types, or those with high $\mathrm{Y}$ and low $\mathrm{Zr} / \mathrm{Y}$, as seen in the barren Western Zone pipes. 
Discussion: The high-temperature garnet population in all the pipes is similar in composition to low-Cr megacryst garnets, and to the overgrowth rims on the garnets of sheared peridotite xenoliths in kimberlite (Griffin et al. 1989b). This is also consistent with their high temperatures of equilibration. This population, and other garnets with high and correlated values of $\mathrm{Ti}$ and $\mathrm{Zr}$, are therefore interpreted as magmatic (megacrysts), and/or as peridotite garnets affected by melt metasomatism; these melts are inferred to be asthenosphere-derived (Smith et al., 1991).

There is essentially no difference in degree of depletion between the Eastern Zone and the Western Zone, in the sense of one having a higher proportion of harzburgitic garnets. The G10 garnets in both the barren pipes of the Eastern Zone and the diamond-bearing pipes of the western zone have relatively high $\mathrm{Cr} 2 \mathrm{O} 3$ (5-10\%), and mostly lie in the T range $900-1050^{\circ} \mathrm{C}$. This places them on the low-T boundary of the diamond stability field, assuming a $40 \mathrm{~mW} / \mathrm{m}^{2}$ geotherm, and shallower than similar garnets from the Kaapvaal craton. The G10 garnets in the barren Western Zone pipes contain 2-3\% Cr2O3, and are all derived from the graphite stability field.

Garnet concentrates from most South African diamondiferous pipes have median $\mathrm{Zr}$ and Y contents of 20-30 and 5-10 ppm, respectively. The barren pipes of both zones in Tanzania contain a high proportion of such depleted lherzolite garnets. In contrast, the garnets from the diamondiferous pipes, including those in the "diamond window", are more fertile, with median $\mathrm{Zr}$ and $\mathrm{Y} \approx 50 \mathrm{ppm}$ and $15 \mathrm{ppm}$, respectively. There is therefore no clear correlation between diamond grade and the fertility of the sampled mantle in these pipes. The data raise the interesting possibility that the deeper parts of the Tanzanian lithosphere are more fertile than the shallower parts, and that this fertility is due to interaction with asthenospheric magmas. A similar process may have affected the Kaapvaal craton, but to a lesser degree (Griffin et al., 1991).

The main difference between the diamond-bearing and barren pipes of the Western Zone is in the depth range sampled by the kimberlites. The barren ones have only sampled quite shallow mantle $(70-100 \mathrm{~km})$, whereas the diamond-bearing ones contain material derived from $120-200 \mathrm{~km}$ deep. Assuming a cratonic geotherm, those in the Eastern Zone have sampled from $100-130 \mathrm{~km}$, and should include some material from the diamond stability field. However, the geotherm in this zone, nearer the craton margin, may be slightly higher than $40 \mathrm{~mW} / \mathrm{m}^{2}$; this would move the intersection of the geotherm with the diamond-graphite stability field to greater depth, and place all of the low-T garnets from the Eastern Zone in the graphite stability field.

Conclusions: At the moment, this study is based on a limited number of pipes, with relatively few garnets from several. However, the results clearly indicate that depth of sampling is the primary control on the diamond potential of kimberlites in the area. The results also demonstrate the usefulness of trace-element analysis of concentrate garnets as a rapid and costeffective tool for the evaluation of diamond exploration targets.

Griffin, W.L., Cousens, D.R., Ryan, C.G., Sie, S.H. and Suter, G.F. 1989a. Contrib. Mineral. Petrol. 103, 199-202.

Griffin, W.L., Smith, D., Boyd, F.R., Cousens, D.R., Ryan, C.G., Sie, S.H. and Suter, G.F. 1989b. Geochim. Cosmochim. Acta 53, 561-567.

Griffin, W.L., Gurney, J.J., Sobolev, N.V. and Ryan, C.G., 1991 (this vol.).

Nixon, P.H. and Condliffe, E. 1989. in Kimberlites and Related Rocks, Vol. 1. Geol. Soc. Australia Spec. Publ. 14. pp. 407-416.

O'Reilly, S.Y. and Griffin, W.L. 1989. Terra Abstracts 1, 9-10.

Smith, D., Griffin, W.L., Ryan, C.G and Sie, S.H. 1991. Contrib. Mineral. Petrol., in press.

\section{FIGURES (next page)}

Fig. 1 (left). $\mathrm{T}_{\mathrm{Ni}}$ histograms for diamondiferous and barren pipes of the Western and Eastern Zones.

Figs. 2 (top right) to 4 (bottom right). Zr-Ti-Y-Ga relations. Squares, W. Zone diamondiferous pipes; circles, W. Zone barren pipes; stars, E. Zone pipes. 

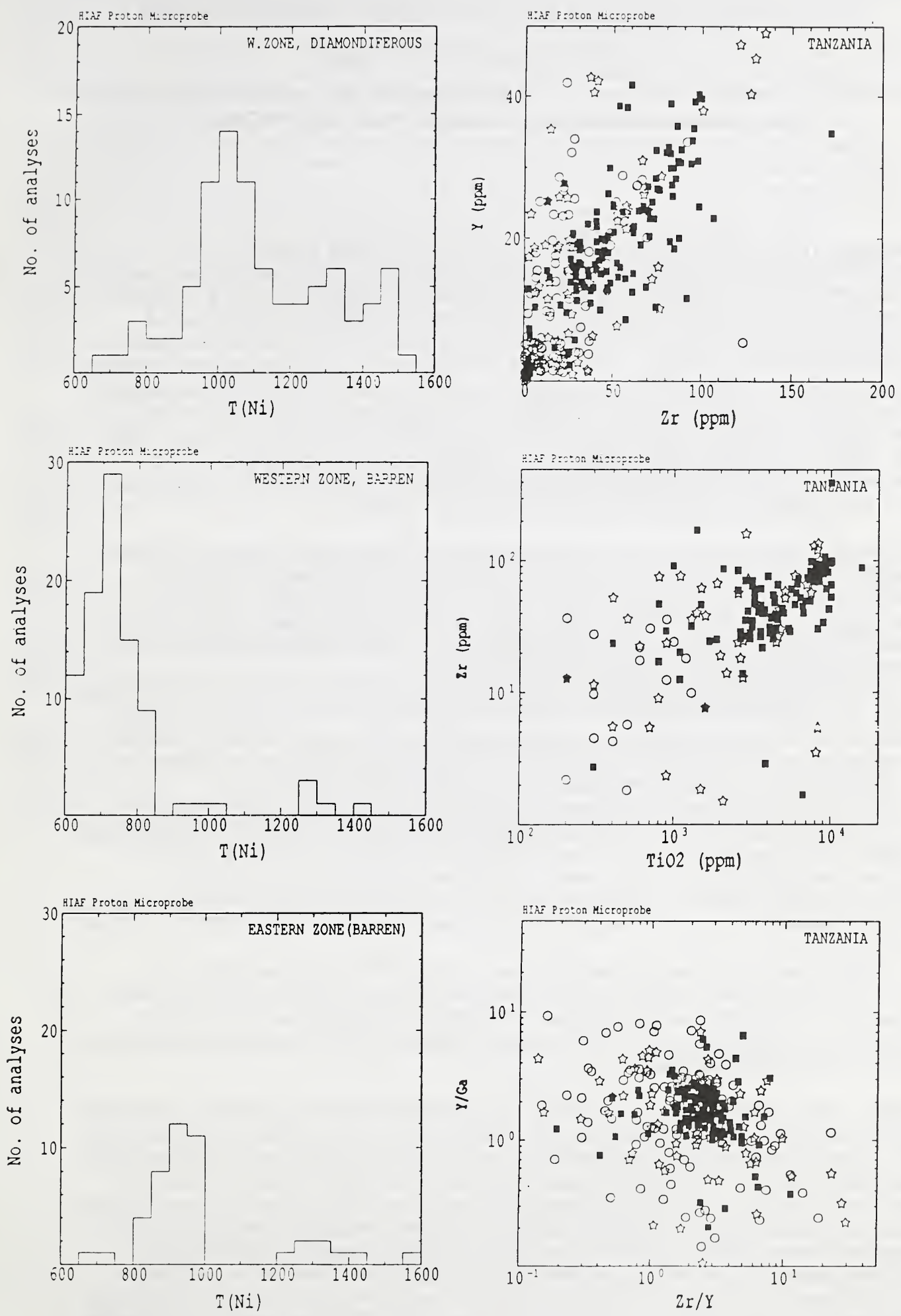